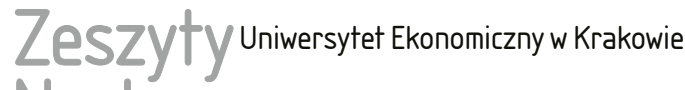 Naukowe
}

\section{Kompleksowe podejście do zapewnienia bezpieczeństwa i ochrony zdrowia pracowników - studium przypadku}

\section{Streszczenie}

Współczesne przedsiębiorstwa coraz częściej stosują systemowe, proaktywne podejście do zarządzania bhp. Wymaga ono kompleksowego i wszechstronnego traktowania zagadnień zdrowia i bezpieczeństwa pracowników. Celem artykułu jest przedstawienie różnorodnych sposobów zapewnienia bezpieczeństwa i ochrony zdrowia pracowników w ramach współczesnego podejścia do zarządzania bhp. Szczególną uwagę zwrócono na kwestie zdrowia organizacyjnego oraz interwencji wpływających na redukcję stresu związanego $\mathrm{z}$ pracą.

Artykuł składa się z dwóch części. Pierwsza ma charakter teoretyczny. Druga stanowi studium przypadku organizacji, która w sposób systemowy zarządza bezpieczeństwem i ochroną zdrowia pracowników. Podjęła ona w tym celu wiele różnorodnych działań o charakterze technicznym, systemowym i behawioralnym. Działania te realizowane są kompleksowo przez służby bhp, działy zarządzania zasobami ludzkimi i jakości oraz osoby odpowiedzialne za medycynę pracy i psychologów zakładowych.

Barbara Chomątowska, Uniwersytet Ekonomiczny we Wrocławiu, Wydział Zarządzania, Informatyki i Finansów, Katedra Zarządzania Produkcją i Pracą, ul. Komandorska 118-120, 53-345 Wrocław, e-mail: barbara.chomatowska@ue.wroc.pl

Dorota Molek-Winiarska, Uniwersytet Ekonomiczny we Wrocławiu, Wydział Zarządzania, Informatyki i Finansów, Katedra Zarządzania Kadrami, ul. Komandorska 118-120, 53-345 Wrocław, e-mail: dorota.winiarska@ue.wroc.pl 
Słowa kluczowe: zarządzanie bezpieczeństwem i ochroną zdrowia, bhp, zdrowie organizacyjne, interwencje, stres.

Klasyfikacja JEL: I12, K32.

\section{Wprowadzenie}

Współczesne poglądy na zarządzanie bezpieczeństwem i higieną pracy są wynikiem kilkudziesięcioletniej ewolucji. Obecnie mamy do czynienia z malejącą liczbą przedsiębiorstw, w których marginalizuje się zagadnienia bezpieczeństwa i zdrowia pracowników, a kadra kierownicza oraz pracownicy nie traktują problemów bezpieczeństwa i higieny pracy jako własnych i nie poświęcają im należytej uwagi. Wzrasta liczba organizacji, dla których skuteczne i efektywne zarządzanie bezpieczeństwem i higieną pracy staje się bardzo ważne. Decyduje o tym nie tylko konieczność przestrzegania przepisów prawnych obowiązujących w tej dziedzinie. J. Ejdys i in. wskazują na trzy główne przesłanki takiego stanu rzeczy. Po pierwsze, społeczeństwa nie chcą już tolerować wypadków przy pracy, w których ludzie giną lub odnoszą ciężkie obrażenia ciała. Po drugie, wymagają podejmowania wszelkich wysiłków w celu zapewnienia bezpieczeństwa i ochrony zdrowia w pracy. Jeśli tak nie jest, odpowiednie instytucje nadzorujące podejmują właściwe kroki, aby poprawić stan bhp. Po trzecie, dbałość o bezpieczeństwo i zdrowie pracowników przynosi przedsiębiorstwu konkretne korzyści. Doświadczenia wielu firm wyraźnie wskazują, że istnieje ścisły związek między skutecznie funkcjonującym systemem zarządzania bhp a wynikami ekonomicznymi przedsiębiorstwa [Ejdys, Lulewicz i Obolewicz 2008, Cascio 2001, Cox, Griffiths i Rial González 2000]. Przedsiębiorstwa mają coraz większą świadomość korzyści ekonomicznych, jakie mogą osiągnąć dzięki właściwemu zarządzaniu bhp oraz kosztów i strat spowodowanych zaniedbaniami w tym obszarze. W związku z tym coraz więcej przedsiębiorstw decyduje się na przyjęcie koncepcji systemowego zarządzania bezpieczeństwem i higieną pracy. W przyjęciu takiego podejścia widzą realne szanse na poprawę procesów i wyników w zakresie bhp oraz swojej konkurencyjności.

$\mathrm{W}$ obliczu zmian zachodzących w warunkach funkcjonowania przedsiębiorstw współczesne podejście do zarządzania bezpieczeństwem i higieną pracy wymaga kompleksowego i wszechstronnego traktowania zagadnień zdrowia i bezpieczeństwa pracowników. Celem niniejszego artykułu jest przedstawienie różnorodnych sposobów zapewniania bezpieczeństwa i ochrony zdrowia pracowników w ramach współczesnego podejścia do zarządzania bhp. Szczególny nacisk położono na model zdrowia organizacyjnego oraz interwencje związane ze zdrowiem zawodowym, a w szczególności stresem związanym z pracą. Artykuł składa się z dwóch części. Pierwsza ma charakter teoretyczny. W drugiej zaprezentowano studium 
przypadku organizacji, która w sposób systemowy i kompleksowy zarządza bezpieczeństwem i ochroną zdrowia pracowników. W realizację celów postawionych przez zarządzających tym obszarem zaangażowane są służby bhp, działy zarządzania zasobami ludzkimi oraz jakości, a także osoby odpowiedzialne za medycynę pracy i psychologowie zakładowi. We wnioskach do niniejszego opracowania wskazano również problemy, które mogą towarzyszyć wprowadzaniu oraz utrzymywaniu kompleksowego oraz proaktywnego podejścia do zarządzania bhp.

\section{Zmiany w podejściu przedsiębiorstw do bezpieczeństwa i zdrowia w pracy}

Norma PN-N-18001: 2004 definiuje bezpieczeństwo i higienę pracy jako stan warunków i organizacji pracy oraz zachowań pracowników zapewniających wymagany poziom ochrony zdrowia i życia przed zagrożeniami występującymi w środowisku pracy [PN-N-18001: 2004]. Według D. Podgórskiego [2008]: „proces rozwoju strategii zarządzania w dziedzinie bezpieczeństwa i higieny pracy rozpoczął się w XIX w. i przebiegał w trzech fazach. Pierwsza faza związana była z pojawieniem się i rozwojem pierwszych regulacji prawnych dotyczących ochrony pracy w krajach uprzemysłowionych i trwała do lat 60. XX w. Druga faza, trwająca do początku lat 80., łączyła się z intensywnym reformowaniem i usprawnianiem systemów ochrony pracy w Europie i USA. Natomiast trzecia faza, zapoczątkowana w drugiej połowie lat 80. i trwająca do dziś, jest związana z normalizacją i upowszechnianiem w skali międzynarodowej metod systemowego zarządzania bhp”. S.A. Herrero i in. [2002] wskazują na trzy główne etapy rozwoju podejścia przedsiębiorstw do zagadnień bezpieczeństwa i higieny pracy, wzorując się przy tym na etapach rozwoju zarządzania jakością. Są nimi kolejno: kontrola bezpieczeństwa (safety control), zapewnianie bezpieczeństwa (safety assurance or guarantee) oraz kompleksowe zarządzanie bezpieczeństwem (total safety management). Warto przy tym podkreślić, że trudno jest dokładnie datować poszczególne fazy rozwoju. Przebiegały one bowiem różnie w różnych krajach, regionach i przedsiębiorstwach. Ponadto w kolejnych fazach stosowano rozwiązania faz wcześniejszych.

W polskich przedsiębiorstwach podejście do zarządzania bezpieczeństwem i higieną pracy zaczęło się zmieniać od połowy lat 90 . Wskazuje się dwa główne powody tych zmian. Pierwszym był proces dostosowywania polskiego prawa w dziedzinie bezpieczeństwa i higieny pracy do prawa Unii Europejskiej. Drugim istotnym powodem było rosnące zainteresowanie przedsiębiorstw systemami zarządzania jakością zgodnymi z normami ISO serii 9000 oraz zarządzania środowiskowego zgodnymi z normami ISO serii 14000. Doprowadziło to w konsekwencji do prób zaadaptowania koncepcji systemowego zarządzania do obszaru 
bezpieczeństwa i higieny pracy [Podgórski 2000]. Informacje o podejmowanych za granicą inicjatywach objęcia zarządzania bezpieczeństwem i higieną pracy zasadami systemowego zarządzania zaowocowały opracowaniem przez Polski Komitet Normalizacyjny serii polskich norm PN-N-18000: PN-N-18001. Systemy zarządzania bezpieczeństwem i higieną pracy. Wymagania; PN-N-18002. Systemy zarządzania bezpieczeństwem i higieną pracy. Ogólne wytyczne do oceny ryzyka zawodowego; PN-N-18004. Systemy zarządzania bezpieczeństwem i higieną pracy. Wytyczne; PN-N-18011. Systemy zarządzania bezpieczeństwem i higieną pracy. Wytyczne audytowania.

Według M.B. Weinsteina [1997] podejście przedsiębiorstw do zarządzania bezpieczeństwem i higieną pracy może odpowiadać jednemu z czterech wyróżnionych przez niego poziomów. Tabela 1 przedstawia krótką charakterystykę każdego $\mathrm{z}$ nich.

Tabela 1. Poziomy zarządzania bezpieczeństwem i higieną pracy

\begin{tabular}{|l|l|l|l|l|l|}
\hline Poziom & $\begin{array}{c}\text { Czynniki } \\
\text { motywujące } \\
\text { do działań } \\
\text { w zakresie BHP }\end{array}$ & \multicolumn{1}{|c|}{$\begin{array}{c}\text { Rodzaj } \\
\text { działania }\end{array}$} & $\begin{array}{l}\text { Główna metoda } \\
\text { oceny }\end{array}$ & $\begin{array}{c}\text { Główne cele } \\
\text { BHP }\end{array}$ & $\begin{array}{c}\text { Osiągane } \\
\text { rezultaty } \\
\text { w obszarze } \\
\text { BHP }\end{array}$ \\
\hline I & Strach & Bierne & $\begin{array}{l}\text { Inspekcje insty- } \\
\text { tucji nadzorują- } \\
\text { cych }\end{array}$ & $\begin{array}{l}\text { Unikać kar } \\
\text { i grzywien }\end{array}$ & $\begin{array}{l}\text { Niepełna zgod- } \\
\text { ność, wyniki } \\
\text { gorsze od } \\
\text { średnich }\end{array}$ \\
\hline II & Kara & Reaktywne & $\begin{array}{l}\text { Analiza } \\
\text { dokumentacji, } \\
\text { inspekcje }\end{array}$ & $\begin{array}{l}\text { Unikać nie- } \\
\text { zgodności }\end{array}$ & $\begin{array}{l}\text { Zgodnóśc } \\
\text { z prawem, } \\
\text { brak poprawy, } \\
\text { wyniki średnie }\end{array}$ \\
\hline IV & $\begin{array}{l}\text { Nagroda } \\
\text { Motywacja }\end{array}$ & Aktywne & $\begin{array}{l}\text { Obserwacja sta- } \\
\text { nowisk pracy, } \\
\text { audyty systemu }\end{array}$ & $\begin{array}{l}\text { Wykonywać } \\
\text { wszystkie prace } \\
\text { poprawnie }\end{array}$ & $\begin{array}{l}\text { Prawidłowe } \\
\text { zachowania, } \\
\text { wyniki lepsze } \\
\text { niż średnie }\end{array}$ \\
\hline
\end{tabular}

Źródło: opracowanie na podstawie [Podgórski 2008].

Podejście do bezpieczeństwa i higieny pracy odowiadające poziomowi I i II określa się mianem tradycyjnego (reaktywnego). Sprowadza się ono najczęściej do działań, których celem jest spełnienie wymagań przepisów prawnych w dziedzinie bhp oraz unikanie kar za ich nierzestrzeganie. Działania te są odizolowane od innych obszarów działalności przedsiębiorstwa, a osoby odpowiedzialne za ich 
realizację bardzo często nie mają formalnych uprawnień do wprowadzania zmian i podejmowania ważnych decyzji w obszarze bhp. Tradycyjne podejście do zarządzania bhp oparte jest przede wszystkim na reagowaniu na zaistniałe zdarzenia (np. wypadki przy pracy) oraz eliminowaniu ich negatywnych skutków. Po wystąpieniu błędu podejmowane są działania, które mają zapobiec podobnym błędom w przyszłości - opracowuje się procedury postępowania, przeprowadza szkolenia, wprowadza zabezpieczenia itd. (por. [Hansen 1993, Sadłowska-Wrzesińska 2014]). Z kolei podejście odpowiadające poziomowi III i IV najczęściej określane jest mianem systemowego, gdyż jest związane $\mathrm{z}$ wdrożeniem w przedsiębiorstwach systemowego zarządzania zasobami, działaniami i procesami ukierunkowanymi na ciągłą poprawę stanu bezpieczeństwa i higieny pracy. Podejmowane działania mają charakter proaktywny. Ich nieodłącznym elementem jest planowanie, zapobieganie u źródła, zanim dojdzie do powstania zagrożenia [Ejdys, Lulewicz i Obolewicz 2008].

\section{Współczesne podejście do bezpieczeństwa i zdrowia pracowników}

Współcześnie kluczowym warunkiem bezpiecznych i zdrowych miejsc pracy jest systematyczne i spójne zarządzanie bezpieczeństwem i higieną pracy. Skuteczność działań na rzecz poprawy stanu bhp wymaga zastosowania systemowego podejścia oraz prowadzenia ich w ramach uporządkowanego systemu zarządzania bhp. Przez system zarządzania bezpieczeństwem i higieną pracy należy rozumieć „część ogólnego systemu zarządzania, która obejmuje strukturę organizacyjną, planowanie, zakres odpowiedzialności poszczególnych podmiotów, zasady postępowania, procedury, procesy i zasoby potrzebne do opracowania, wdrażania, realizowania, przeglądu i utrzymywania polityki bezpieczeństwa i higieny pracy" [PN-N-18001: 2004]. Należy podkreślić, że system zarządzania bezpieczeństwem i higieną pracy powinien być częścią ogólnego systemu zarządzania organizacją, tzn. nie może być rozpatrywany i analizowany jako mniej istotny dodatek do „ważniejszych” procesów zarządzania, co było charakterystyczne dla tradycyjnego podejścia, lecz powinien mieć taką samą rangę jak pozostałe działania w organizacji i funkcjonować w niej w sposób w pełni zintegrowany z innymi procesami zarządzania [Podgórski 2017, Thompson i Hopwood 2017]. Sukces systemu zarządzania bezpieczeństwem i higieną pracy uzależniony jest od wielu czynników. Norma PN-N-18001: 2004 uzależnia go przede wszystkim od zaangażowania wszystkich służb na wszystkich poziomach organizacji, w szczególności najwyższego kierownictwa, a także zapewnienia szerokiego współudziału pracowników na etapie projektowania, wdrażania i utrzymywania wszystkich elementów tego 
systemu. Proponowany przez normę model systemu zarządzania bhp oparty jest na koncepcji ciągłego doskonalenia i obejmuje następujące elementy [PN-N-18001: 2004]:

1) zaangażowanie najwyższego kierownictwa w politykę bezpieczeństwa i higieny pracy;

2) planowanie działań ukierunkowanych na osiągnięcie celów ogólnych i szczegółowych organizacji dotyczących bhp, uwzględniające wyniki identyfikacji zagrożeń i oceny ryzyka zawodowego;

3) wdrażanie i funkcjonowanie, w tym:

- ustalenie struktury, odpowiedzialności i uprawnień,

- zapewnienie zasobów (finansowych, rzeczowych, ludzkich itd.) potrzebnych do wdrożenia, funkcjonowania i nadzorowania systemu,

- zapewnienie dostosowanych do potrzeb poszczególnych grup pracowników programów szkoleń w dziedzinie bhp, rozwój kompetencji pracowników w zakresie bhp i stosowanie odpowiednich metod motywowania pracowników do ich angażowania się w działania na rzecz poprawy bhp,

- komunikowanie się,

- dokumentowanie systemu zarządzania bezpieczeństwem i higieną pracy (m.in. procedury identyfikacji zagrożeń oraz oceny związanego z nimi ryzyka zawodowego),

- planowanie oraz organizowanie prac i działań związanych ze znaczącymi zagrożeniami,

- zapobieganie oraz gotowość do reagowania na wypadki przy pracy i poważne awarie;

4) sprawdzanie funkcjonowania systemu obejmujące monitorowanie (reaktywne i proaktywne), badanie wypadków przy pracy, chorób zawodowych i zdarzeń potencjalnie wypadkowych, audyt oraz działania korygujące i zapobiegawcze;

5) przegląd systemu zarządzania bhp wykonywany przez najwyższe kierownictwo i ciągłe doskonalenie systemu jako całości oraz jego poszczególnych elementów.

Zarządzanie bezpieczeństwem i higieną pracy w obecnych warunkach funkcjonowania przedsiębiorstw nie jest łatwym zadaniem. Sytuację komplikują zmiany dotyczące pracy, miejsc i warunków pracy. Obok znanych pojawiają się nowe, słabo rozpoznane zagrożenia dla zdrowia i życia pracowników, wymagające odmiennych niż do tej pory metod diagnozy oraz profilaktyki. Według D. Koradeckiej „ogromny postęp techniki nie rozwiązał problemów bezpieczeństwa i ochrony zdrowia w środowisku pracy. Przeniósł jedynie punkt ciężkości z zagrożeń fizycznych, chemicznych i pyłowych na psychofizyczne i biologiczne. Ochrona pracy musi więc obecnie bardziej niż kiedykolwiek postawić w centrum swoich zainteresowań człowieka wraz z jego ograniczonymi możliwościami psychofizycznymi 
w środowisku pracy" [Bezpieczeństwo i higiena... 2008]. Zachodzące zmiany oznaczają, że zarządzanie bezpieczeństwem i ochroną zdrowia pracowników rozwija się w kierunku holistycznego, kompleksowego oraz interdyscyplinarnego postrzegania zagadnień bezpieczeństwa i zdrowia człowieka w środowisku pracy. Wiąże się to z koniecznością zastosowania innowacyjnych metod i narzędzi zarządzania bhp, adaptowania sprawdzonych rozwiązań z innych dziedzin. Nasilają się również tendencje integrowania systemu zarządzania bezpieczeństwem i higieną pracy z innymi systemami zarządzania (jakością, środowiskiem). Sprzyjają temu przeprowadzone w 2015 r. nowelizacje norm ISO dotyczących zarządzania jakością i środowiskiem oraz prace nad pierwszą międzynarodową normą ISO dotyczącą bezpieczeństwa i higieny pracy - ISO 45001.

W wielu przedsiębiorstwach konieczna staje się rewizja dotychczasowego podejścia do zdrowia pracowników. Przede wszystkim istotne jest zrozumienie, że zgodnie z definicją przyjętą i propagowaną przez WHO zdrowie to stan pełnego dobrostanu psychicznego, fizycznego i społecznego, a nie tylko braku choroby (http://www.who.int/about/mission/en/, data dostępu: 14.01.2017). Takie postrzeganie zdrowia pracownika oznacza m.in., że celem podmiotów odpowiedzialnych za kwestie bhp jest nie tylko ochrona zdrowia pracowników, ale również jego umacnianie i rozwój, czyli tzw. promocja zdrowia (por. [Graveling i in. 2008, Molek-Winiarska 2010, Nielsen i in. 2010, Puchalski i Korzeniowska 2008]). W poszukiwaniu odmiennych niż do tej pory sposobów ochrony zdrowia pracowników może pomóc odniesienie się do koncepcji zdrowia organizacyjnego (organizational health). Pojęcie zdrowia organizacyjnego (ZO) nie zostało do tej pory jednoznacznie zdefiniowane (por. [Kipfelsberger, Herhausen i Bruch 2016]). Najczęściej określa się je jako pewną kombinację zdrowia pracownika i wydajności organizacji [Cotton i Hart 2003, Miles 1969]. Zdrowie organizacyjne rozpatruje się jako konstrukt trójwymiarowy obejmujący psychologiczne, fizyczne i metafizyczne wymiary dobrostanu [Quick, Macik-Frey i Cooper 2007, MacIntosh, Maclean i Burns 2007]. G. Bauer i G. Jenny [2012] wyodrębnili trzy nurty w ramach badań nad ZO. Pierwszy z nich traktuje je w kategoriach zaburzeń i odstępstw od normy. Nurt ten jest najczęściej związany z badaniami i interwencjami z zakresu stresu zawodowego oraz dysfunkcji i patologii w środowisku pracy. Zdrowie organizacyjne jest więc stanem radzenia sobie z patologicznymi czynnikami organizacyjnymi i przewagi indywidualnie postrzeganych zasobów nad wymaganiami środowiska pracy [Cooper i Payne 1987, Cox, Griffiths i Rial González 2000, Karasek 1979, Miller, Griffin i Hart 1999, Siegrist 1996]. Drugi nurt badawczy definiuje zdrowie organizacyjne w kategoriach zasobów wpływających na pozytywne procesy i dyspozycje w organizacji. Motywacja, aspiracje, poczucie skuteczności, zaangażowanie, satysfakcja to elementy zdrowia organizacyjnego badane i opisywane w tym nurcie [Bakker i Schaufeli 2008, Juchnowicz 2012, Robbins 2004]. 
Trzecia grupa badaczy tworzy nurt psychologii salutogenicznej i łączy zdrowie zawodowe z takimi koncepcjami, jak: społeczna odpowiedzialność biznesu, rozwój organizacyjny, prospołeczne i obywatelskie zachowania, podejście doceniające (appreciative inquiry). Zdrowie zawodowe w tym nurcie definiowane jest przez połączenie psychologii pozytywnej i koncepcji pozytywnego zdrowia z perspektywą patogeniczną i terminem złego zdrowia [Bauer, Davies i Pelikan 2006, Bauer i Jenny 2012]. Na rys. 1 przedstawiono zależności między organizacją a jednostką, w wyniku których jednostka charakteryzuje się dobrym lub złym (słabym) zdrowiem, co bezpośrednio wpływa na wyniki ekonomiczne organizacji.

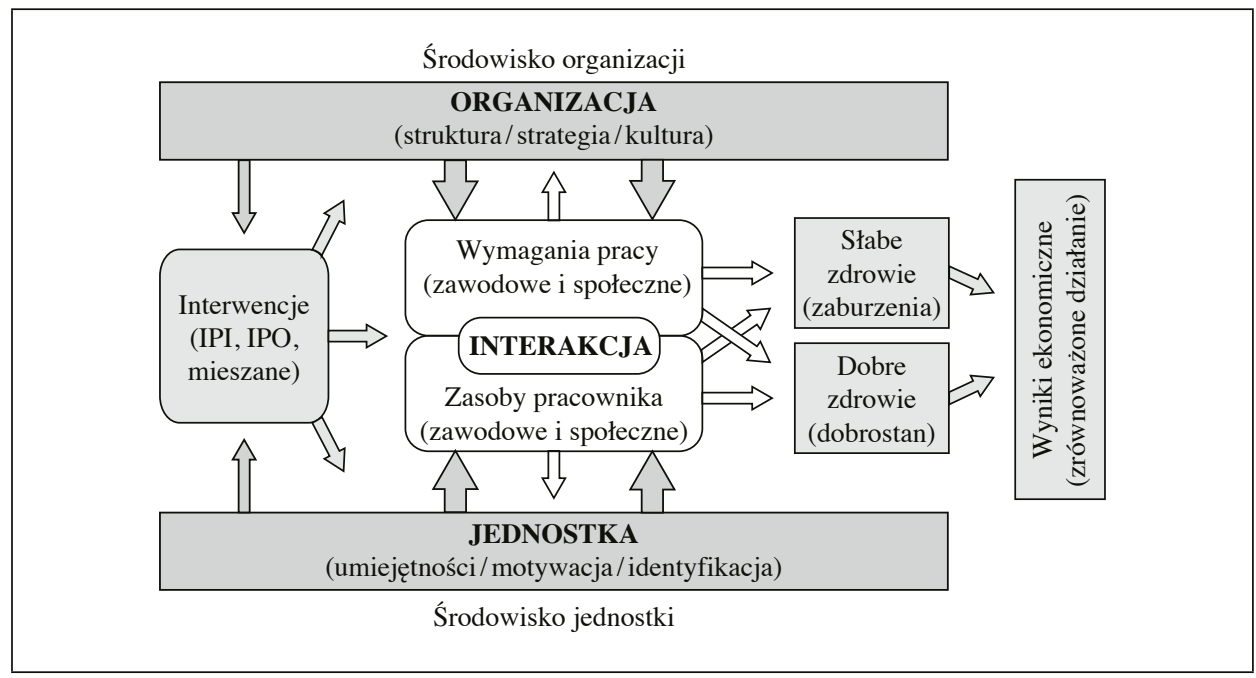

Rys 1 . Model zdrowia organizacyjnego

Źródło: opracowanie własne na podstawie [Bauer i Jenny 2012].

W literaturze przedmiotu można znaleźć wiele klasyfikacji działań związanych z poprawą zdrowia zawodowego. Działania te określa się mianem programów redukcji stresu (stress management interventions), interwencji związanych ze zdrowiem zawodowym (interventions in occupational health), programów skoncentrowanych na dążeniu do równowagi między pracą a życiem prywatnym (work-life balance initiatives). Niezależnie od nazwy działania takie definiuje się jako oparte na teorii naukowej oraz finansowane przez pracodawcę akcje, których celem jest zrównoważenie wymagań związanych z pracą, poprawa zdrowia zawodowego i dobrostanu pracownika [Cascio 2001, Nielsen i in. 2010], a także poprawa wyników ekonomicznych organizacji przez podnoszenie efektywności kapitału ludzkiego [Sinclair i in. 2010, Brummelhuis i Lippe 2010]. 
Ze względu na cel działania, można mówić o trojakim podziale interwencji [Cox, Griffiths i Rial González 2000, Dalgren i Gard 2009, Molek-Winiarska 2010, Richardson i Rothstein 2008, Sinclair i in. 2010]:

- pierwszego stopnia (primary) - koncentracja na diagnozowaniu i eliminowaniu bądź redukowaniu źródeł i kosztów patologii w organizacji,

- drugiego stopnia (secondary) - wspieranie pracowników w radzeniu sobie $\mathrm{z}$ istniejącym stresem, promowanie praktyk prozdrowotnych, rozwijanie zasobów indywidualnych w zakresie działań salutogenicznych,

- trzeciego stopnia (tertiary) - podejmowanie działań prowadzących do przywrócenia zdrowia psychosomatycznego, pomoc psychologiczna lub medyczna w zmaganiu się ze skutkami stresu lub innych patologii w pracy.

Interwencje można również podzielić na takie, które wdrażane są na poziomie organizacyjnym (organizational level interventions) - IPO, oraz na poziomie jednostki (individual level interventions) - IPJ [Cooper, Liukkonen i Cartwright 1996, Cox, Griffiths i Rial González 2000, Dalgren i Gard 2009, Dewe i O'Driscoll 2002, Graveling i in. 2008, Richardson i Rothstein 2008, Klink i in. 2001]. Przykładowe IPO to: kontrola i poprawa ergonomii stanowisk pracy, wprowadzanie zmian w zakresie organizacji pracy (np. elastyczne formy czasu pracy, rotacja pracy, modyfikacje w zakresie zmianowego systemu pracy), definiowanie ról zawodowych w celu uzyskania ich klarowności i uniknięcia konfliktu, przeciążenia czy też niejednoznaczności roli. Programy typu IPJ to: szkolenia z zakresu umiejętności radzenia sobie ze stresem, promocja zdrowia w zakresie zdrowego trybu życia i aktywności fizycznej, szkolenia w zakresie relaksacji, medytacji, treningu uważności (mindfulness-based stres reduction-MBSR) i in.

\section{Studium przypadku}

Metodą badawczą zastosowaną w prezentowanym badaniu jest studium przypadku. Przedstawiono przedsiębiorstwo z branży wydobywczej. Organizacja zatrudnia 3300 osób, z czego dwie trzecie stanowią osoby na stanowiskach wykonawczych oraz kierowniczych niższego szczebla pracujące pod ziemią. Przedsiębiorstwo należy do korporacji, która jest liderem w branży górniczej. Zakład istnieje już prawie 60 lat. Główną działalnością jest wydobycie urobku. Kopalnia dysponuje siedmioma szybami o głębokości 500-1000 m, z których jeden jest szybem wydobywczym, a pozostałe pełnią funkcje zjazdowo-materiałowe i wentylacyjne. Średnie dobowe wydobycie wynosi ponad 27 tys. ton urobku.

Jedną z głównych wartości przyjętych przez organizację jest bezpieczeństwo i zdrowie pracowników obok współdziałania, zorientowania na wyniki, odpowiedzialności i odwagi. W firmie podejmuje się wiele skoordynowanych działań 
mających na celu odzwierciedlenie tych wartości w codziennym funkcjonowaniu. W celu stworzenia bezpiecznych i higienicznych warunków pracy przedsiębiorstwo zdecydowało się na przyjęcie systemowego podejścia do zarządzania bezpieczeństwem i higieną pracy. W 2013 r. wdrożyło system zarządzania bhp zgodnie z wymaganiami zawartymi w polskiej normie PN-N-18001. Realizacją zadań z obszaru bhp w przedsiębiorstwie zajmuje się przede wszystkim dział bhp oraz pełnomocnik ds. zagrożeń i bezpieczeństwa pracy. Warto zaznaczyć, że zgodnie z polityką bhp firmy dbałość o bezpieczeństwo i zdrowie jest sprawą wszystkich pracowników na każdym szczeblu zarządzaniu. Pracownicy przedsiębiorstwa dokładają starań, by określony w strategii biznesowej cel „zero strat - zero szkód” został osiągnięty w jak najkrótszej perspektywie. Dlatego podejmowane przez nich działania na rzecz ciągłego doskonalenia poziomu bezpieczeństwa i zdrowia pracowników mają charakter proaktywny i dobrowolny, tzn. wychodzą daleko poza sferę praktyk określonych przepisami prawa. Podejście to jest wynikiem zobowiązania przedsiębiorstwa wobec własnych pracowników, ale także kilku tysięcy pracowników firm zewnętrznych realizujących prace na jego rzecz.

Przedsiębiorstwo w ramach wdrożonego, utrzymywanego i ciągle doskonalonego systemu zarządzania bezpieczeństwem i higieną pracy podejmuje różnorodne działania. Takie podejście ma przede wszystkim zapewnić możliwie najbardziej kompleksową ochronę bezpieczeństwa i zdrowia pracowników. Oprócz działań na rzecz bezpieczeństwa systemowego (np. ocena ryzyka zawodowego, audyty, przeglądy zarządzania) przedsiębiorstwo równolegle realizuje zadania mające na celu poprawę bezpieczeństwa technicznego (np. zakup nowoczesnych maszyn, zabezpieczenia urządzeń) oraz behawioralnego (audyty behawioralne, badania kultury bhp) (por. [Koźlik 2008]). Warto podkreślić, że organizacja dokłada wszelkich starań, aby pomimo różnorodności działania te były spójne i zgodne z ustaloną polityką oraz celami bezpieczeństwa i higieny pracy. Firma skutecznie zabiega również o zapewnienie szerokiego współudziału pracowników w ich realizacji. Poniżej przedstawiono listę wybranych działań na rzecz poprawy stanu bhp realizowanych przez badane przedsiębiorstwo:

- systematyczna identyfikacja zagrożeń i ocena związanego z nimi ryzyka zawodowego, podejmowanie działań mających na celu eliminację lub ograniczenie jego poziomu;

- monitorowanie i stała ewaluacja opisów stanowisk pracy ze szczególnym naciskiem na charakterystykę zagrożeń zawodowych oraz działania, jakie podejmowane są w celu zapobiegania zagrożeniom;

- w ramach bezpieczeństwa technicznego, poprawy ergonomii: zakup i wykorzystanie najnowocześniejszych sprzętów, maszyn i urządzeń, by utrzymać jak najwyższy poziom bezpieczeństwa i standardu pracy, np. klimatyzowane kabiny w maszynach, mechanizacja eksploatacji górniczej przez wprowadzenie zdalnie 
sterowanych maszyn i systemów monitoringu, a także systemy chroniące ludzi w pracy pod ziemią (np. maszyny wyposażane w kabiny kapsułowe ochraniające operatora czy kamery zwiększające pole widzenia podczas manewrowania oraz wizualizację newralgicznych odcinków przenośników taśmowych, takich jak: wysięgnik, napęd, pętlica, punkty wysypowe urobku, przesypy);

- w celu podniesienia bezpieczeństwa procesu pracy zainstalowanie systemu wczesnego reagowania pozwalającego na stałe monitorowanie stanu środowiska pracy, m.in. dzięki automatyzacji procesu sterowania siecią elektroenergetyczną (system wizualizacji stanu pracy urządzeń elektroenergetycznych) i monitoringowi zapylenia powietrza oraz zanieczyszczenia wód;

- prowadzenie prac badawczych w zakresie profilaktyki zagrożenia zawałami oraz konstruowanie prototypów urządzeń pomiarowych, które poddawane są procesowi wzorcowania i kalibracji;

- wdrożenie metodologii lean do procesów produkcyjnych przedsiębiorstwa (TPM, 5S), identyfikacja i monitoring 5-10\% krytycznych miejsc pracy, wyróżnienie i monitoring miejsc szczególnie niebezpiecznych, audyty stanowisk pracy;

- ustalenie jednolitego sposobu liczenia kosztów wypadków przy pracy oraz dokonywanie analiz porównawczych między wszystkimi oddziałami firmy;

- wprowadzenie metod i narzędzi pomiaru efektów wdrożenia programów utrzymania i polepszania kondycji psychicznej i zdrowia pracowników z wykorzystaniem wiedzy z badań prowadzonych w Europie (Szwajcaria, Niemcy, Wielka Brytania); wśród stosowanych metod są: resource/demand ratio, analiza efektywności kosztów, zwrotu z inwestycji (ROI);

- uruchomienie i wdrożenie programów edukacyjnych i szkoleniowych, kampanii informacyjnych, których celem jest przede wszystkim zwrócenie uwagi pracowników na to, że lekceważenie przepisów, procedur bezpieczeństwa pracy w przypadku zagrożeń związanych z oberwaniem się mas i brył skalnych może prowadzić do tragicznych skutków;

- uruchomienie centrum profilaktyki medycznej; pracownicy mają dostęp do niepublicznej opieki medycznej, każdemu z nich przysługuje pakiet badań, który rokrocznie może wykorzystać na badanie zdrowia fizycznego;

- uruchomienie programów zdrowotnych podnoszących sprawność fizyczną i samodyscyplinę pracowników;

- wprowadzenie programów szybkiego powrotu do zdrowia po wypadkach;

- kształtowanie i badanie poziomu kultury bezpieczeństwa i higieny pracy.

Jednym z wyzwań w zakresie bezpieczeństwa i zdrowia pracowników, z jakim zmierzyło się przedsiębiorstwo, są zagrożenia psychospołeczne i stres związany $\mathrm{z}$ pracą. $\mathrm{W}$ tym celu organizacja:

- powołała centrum pomocy psychologicznej dla osób, które uczestniczyły w niebezpiecznych zdarzeniach, jak również dla ich rodzin; 
- wdrożyła pilotażowy program redukcji stresu dostosowany do specyfiki pracy w kopalni. Program obją̨ 76 pracowników na stanowiskach wykonawczych oraz pracowników dozoru. Jego celem była diagnoza, a następnie plan i wdrożenie interwencji skierowanej na redukcję tych źródeł stresu pracowników, które zostały określone w diagnozie psychologicznej. Interwencję przeprowadzono z wykorzystaniem treningu psychologicznego (16 godzin) oraz treningu uważności (40 godzin). Efektem programu było znaczące zwiększenie umiejętności radzenia sobie ze stresem, wzrost satysfakcji z pracy oraz poprawa ogólnego zdrowia psychologicznego;

- opierając się na wdrożonym programie, zdecydowała się na stały monitoring czynników zagrożeń psychospołecznych, które mogłyby przyczynić się do spadku produktywności pracy i mieć poważne konsekwencje zdrowotne i psychologiczne dla pracowników. W tym celu przeprowadzono diagnozy psychologiczne poziomu stresu zawodowego oraz zagrożeń psychospołecznych. Badaniami objęto ponad 1200 pracowników, co stanowiło jedną trzecią wszystkich pracowników zatrudnionych w firmie oraz ponad połowę tych, którzy pracują pod ziemią. Zostali oni zaproszeni do udziału w diagnozach psychologicznych, na podstawie których uzyskano informacje dotyczące rodzaju i intensywności źródeł stresu zawodowego, obciążenia psychologicznego związanego z wykonywaną pracą oraz poziomu ogólnego zdrowia psychologicznego. Raporty z diagnoz przyczyniły się do stworzenia planów rozwojowych w tym obszarze.

W najbliższej przyszłości firma planuje kontynuację programu redukcji stresu w kolejnych grupach pracowniczych we wszystkich oddziałach firmy, wzbogacenie go w zakresie diagnozy psychologicznej oraz badań jakościowych stanowiących nowy trend w procedurze wdrażania programów redukcji stresu. Planowane jest rozszerzenie istniejących programów na działania o charakterze długofalowych programów w zakresie utrzymywania równowagi między pracą a życiem (work-life balance).

Realizacja zadań z obszaru zarządzania bezpieczeństwem i higieną pracy wymaga ścisłej współpracy i wymiany informacji pomiędzy służbami bhp a pozostałymi działami firmy oraz specjalistami z zewnątrz (np. psycholodzy, lekarze medycyny pracy). W tym celu w firmie stworzono specjalny system przepływu informacji pomiędzy wszystkimi podmiotami zaangażowanymi w proces poprawy stanu bhp. Kierownicy i specjaliści poszczególnych jednostek mają systematyczne spotkania, na których prezentowane są plany oraz osiągnięcia implementacyjne w zakresie bezpieczeństwa i higieny pracy. Projekty, które przyniosły pozytywne rezultaty, wdrażane są w pozostałych oddziałach firmy. Warto w tym miejscu podkreślić ważną rolę działu zarządzania zasobami ludzkimi - przez swoje działania i narzędzia personalne w istotny sposób wspiera on realizację założonych przez przedsiębiorstwo celów bhp. Na szczególną uwagę zasługują: 
- prowadzenie systematycznych ocen pracowniczych, w których dokonuje się ewaluacji pracowników m.in. w zakresie indywidualnych działań podjętych w obszarze dbałości o zdrowie fizyczne i psychologiczne, znajomości i poziomu realizacji zaleceń BHP w codziennej pracy;

- prowadzenie systematycznych szkoleń dotyczących wzmacniania potencjału psychologicznego, automotywacji, umiejętności jasnego przekazu informacji, rozwoju poczucia odpowiedzialności indywidualnej i zespołowej oraz rozwiązywania konfliktów.

- prowadzenie rozmów z pracownikami w zakresie oceny stopnia radzenia sobie ze stresem i innymi obciążeniami psychospołecznymi.

\section{Wnioski}

Przedstawioną organizację wybrano nie tylko ze względu na możliwość ukazania przykładu nowoczesnego, kompleksowego oraz proaktywnego podejścia do zarządzania bezpieczeństwem i ochroną zdrowia pracowników, ale również wskazania potencjalnych problemów, które mogą towarzyszyć jego wprowadzaniu oraz skutecznemu utrzymywaniu. W przypadku omawianego przedsiębiorstwa zwraca się uwagę na potrzebę interdyscyplinarnego podejścia, łączącego wiedzę ekonomiczną, psychologiczną, technologiczną oraz z obszaru zarządzania. Nie zawsze istnieje możliwość uzyskania takiej różnorodności zasobów w organizacji. Wyzwanie stanowią również: sprawny przepływ informacji, potrzeba wzajemnego zrozumienia, budowanie zaangażowania kierownictwa oraz pracowników wykonawczych w realizację celów bhp, komunikacja pomiędzy różnymi działami pracującymi nad poprawą bhp. Istotne jest tworzenie zespołów interdyscyplinarnych oraz stosowanie mierników oceny skuteczności oraz efektywności podejmowanych działań.

Przyjęcie systemowego, opartego na planowaniu i prewencji podejścia do zarządzania bezpieczeństwem i higieną pracy jest dużym wyzwaniem dla przedsiębiorstw (szczególnie dla tych, które długo zarządzały bhp w sposób tradycyjny). Opracowanie, wdrożenie, utrzymanie oraz ciągłe doskonalenie systemu zarządzania bhp jest zadaniem złożonym, wymagającym zaangażowania wszystkich pracowników na wszystkich szczeblach zarządzania. Ponadto zmieniające się warunki funkcjonowania współczesnych organizacji wymagają tego, aby systemy zarządzania bhp ewoluowały w stronę rozwiązań, które pozwolą sprostać coraz ambitniejszym celom w zakresie kształtowania kapitału ludzkiego w organizacji. Zarządzający powinni w tym celu otworzyć się na nową wiedzę, idee, różnorodne sposoby kształtowania bezpiecznego, zdrowego i ergonomicznego środowiska pracy. Duże znaczenie mają dobre przykłady płynące z firm, które z sukcesem, 
w sposób kompleksowy i zintegrowany z innymi obszarami działalności zarządzają bezpieczeństwem i ochroną zdrowia pracowników [The DuPont... 2012]. Przede wszystkim są one źródłem nowatorskich, wartościowych i sprawdzonych rozwiązań, które mogą pomóc przedsiębiorstwom w przejściu na wyższy poziom zarządzania bhp. Dostarczają one również cennej wiedzy na temat różnych problemów, które organizacje mogą napotkać, zarządzając bezpieczeństwem i ochroną zdrowia swoich pracowników, oraz radzenia sobie z nimi.

\section{Literatura}

Bakker A., Schaufeli W., Leiter M., Taris T. [2008], Work Engagement: An Emerging Concept in Occupational Health Psychology, ,Work and Stress”, vol. 22, nr 3, https:// doi.org/10.1080/02678370802393649.

Bauer G.F., Davies J.K., Pelikan J. [2006], The EUHPID Health Development Model for the Classification of Public Health Indicators, „Health Promotion International”, vol. 21, nr 2, https://doi.org/10.1093/heapro/dak002.

Bauer G.F., Jenny G. [2012], Moving Towards Positive Organizational Health: Challenges and a Proposal for a Research Model of Organizational Health Development [w:] Contemporary Occupational Health Psychology, eds J. Houdmont, S. Leka, R. Sinclair, Wiley-Blackwell, West Sussex.

Bezpieczeństwo i higiena pracy [2008], red. D. Koradecka, Centralny Instytut Ochrony Pracy, Państwowy Instytut Badawczy, Warszawa.

Brummelhuis L. ten, Lippe T. van de [2010], Effective Work-life Balance Support for Various Household Structures, „Human Resource Management”, vol. 49, nr 2, https:// doi.org/10.1002/hrm.20340.

Cascio W. [2001], Kalkulacja kosztów zasobów ludzkich, Oficyna Ekonomiczna, Kraków. Cooper C.L., Liukkonen P., Cartwright S. [1996], Stress Prevention in the Workplace, European Foundation for Improvement of Living and Working Conditions, Dublin.

Cooper C.L., Payne R. [1987], Stres w pracy, PWN, Warszawa.

Cotton P., Hart M.P. [2003], Occupational Wellbeing and Performance: A Review of Organizational Health Research, „Australia Psychologist”, vol. 38, $\mathrm{nr}$ 2. https://doi. org/10.1080/00050060310001707117.

Cox T., Griffiths A., Rial González E. [2000], Research on Work-related Stress, Report EU OSHA, Nottingham, https://osha.europa.eu/pl/ publications/reports/203 (data dostępu: 17.08.2010).

Dalgren A., Gard G. [2009], Soft Values with Hard Impact - a Review of Stress Reducing Interventions on Group and Organizational Level, „Physical Therapy Reviews”, vol. 14, nr 6, https://doi.org/10.1179/108331909x12540993897810.

Dewe P., O'Driscoll M. [2002], Stress Management Interventions: What Do Managers Actually Do?, „Personnel Review”, vol. 31, nr 1-2, https://doi.org/10.1108/ 00483480210416847.

The DuPont Integrated Approach (DnA) for Safety: A Catalyst to Accelerate Performance [2012], http://www.dupont.com/content/dam/dupont/products-and-services/consulting-services-and-process-technologies/consulting-services-and-process-technologieslanding/documents/DnA_USA_Brochure_06192012.pdf (data dostępu: 14.01.2017). 
Ejdys J., Lulewicz A., Obolewicz J. [2008], Zarzq̨dzanie bezpieczeństwem w przedsiębiorstwie, Wydawnictwo Politechniki Białostockiej, Białystok.

Graveling R.A., Crawford J.O., Cowie H., Amati C., Vohra S. [2008], A Review of Workplace Interventions that Promote Mental Wellbeing in the Workplace, Institute of Occupational Medicine, Edinburgh.

Hansen L. [1993], Safety Management: A Call for Revolution, „Professional Safety”, vol. $38, \mathrm{nr} 3$.

Herrero S.G., Saldana M.A.M, Manzanedo del Campo M.A., Ritzel D.O. [2002], From the Traditional Concept of Safety Management to Safety Integrated with Quality, ,Journal of Safety Research, vol. 33, nr 1, https://doi.org/10.1016/s0022-4375(02)00008-7.

Juchnowicz M. [2012], Satysfakcja z pracy w sektorze usług $w$ realiach polskiej gospodarki, ,Edukacja Ekonomistów i Menedżerów. Problemy, Innowacje, Projekty”, nr 24.

Karasek R. [1979], Job Demands, Job Decision Latitude and Mental Strain: Implications for Job Redesign, „Administrative Science Quarterly”, nr 24, https://doi.org/ $10.2307 / 2392498$.

Kipfelsberger P., Herhausen D., Bruch H. [2016], How and When Customer Feedback Influences Organizational Health, ,Journal of Managerial Psychology”, vol. 31, nr 2, https://doi.org/10.1108/JMP-09-2014-0262.

Klink J.J.L. van der, Blonk R.W.B, Schene A.H., Dijk F.J.H. van [2001], The Benefits of Interventions for Work-related Stress, ,American Journal of Public Health”, vol. 91, nr 2, https://doi.org/10.2105/ajph.91.2.270.

Koźlik M. [2008], Kompleksowe podejście do bezpieczeństwa pracy, „Przyjaciel przy Pracy", nr 10.

MacIntosh R., Maclean D., Burns H. [2007], Health in Organizations: Towards a Process-based Approach, ,Journal of Management Studies”, vol. 44, nr 2, https://doi. org/10.1111/j.1467-6486.2007.00685.x.

Miles M.B. [1969], Planned Change and Organizational Health: Figure and Ground [w:] Organizations and Human Behavior, eds F.D. Carver, T.J. Sergiovanni, McGraw-Hill, New York.

Miller R.L., Griffin M.A., Hart P. [1999], Personality and Organizational Health: The Role of Conscientiousness, „International Journal of Work, Health and Organisations”, vol. 13, nr 1, https://doi.org/10.1080/026783799296156.

Molek-Winiarska D. [2010], Organizacyjne i indywidualne programy zarzqdzania stresem, „Współczesne Zarządzanie”, nr 1.

Nielsen K., Randall R., Holten A., Gonzalez E. [2010], Conducting Organizational-level Occupational Health Interventions: What Works?, „Work and Stress”, vol. 24, nr 3, https://doi.org/10.1080/02678373.2010.515393.

PN-N-18001:2004 Systemy zarządzania bezpieczeństwem i higieną pracy. Wymagania [2004], PKN, Warszawa.

PN-N-18004:2001 Systemy zarządzania bezpieczeństwem i higieną pracy. Wytyczne [2001], PKN, Warszawa.

Podgórski D. [2000], Systemowe zarzqdzanie bezpieczeństwem i higienq pracy - normalizacja i promocja, ,Bezpieczeństwo Pracy”, nr 12.

Podgórski D. [2008], Metody i modele systemów zarzqdzania bezpieczeństwem i higienq pracy [w:] Bezpieczeństwo i higiena pracy, red. D. Koradecka, Centralny Instytut Ochrony Pracy, Państwowy Instytut Badawczy, Warszawa.

Podgórski D. [2017], Współczesne koncepcje zarzqdzania bezpieczeństwem i higienq pracy [w:] Nauka o pracy, bezpieczeństwo, higiena, ergonomia. Pakiet edukacyjny dla 
uczelni wyższych, Centralny Instytut Ochrony Pracy, http://nop.ciop.pl/m8-1/m8-1_1. htm (data dostępu: 17.01.2017).

Puchalski K., Korzeniowska E. [2008], Promocja zdrowia w miejscu pracy w politykach zdrowia publicznego w Polsce, ,Medycyna Pracy”, vol. 59, nr 1.

Quick J.C., Macik-Frey M., Cooper C.L. [2007], Managerial Dimensions of Organizational Health: The Healthy Leader at Work, ,Journal of Management Studies”, vol. 44, nr 2, https://doi.org/10.1111/j.1467-6486.2007.00684.x.

Richardson K.M., Rothstein R.H. [2008], Effect of Occupational Stress Management Intervention Programs. A Meta-analysis,,Journal of Occupational Health Psychology”, vol. 13, nr 1, https://doi.org/ 10.1037/1076-8998.13.1.69.

Robbins S.P. [2004], Organizational Behavior. Concepts, Controversies and Applications, Prentice-Hall, International Editions.

Sadłowska-Wrzesińska J. [2014], Bezpieczeństwo behawioralne (BBS), społeczna odpowiedzialność biznesu (CSR) i dialog społeczny - współczesne wyzwania bezpieczeństwa pracy [w:] Innowacje w zarzqdzaniu i inżynierii produkcji, t. 2, red. R. Knosala, Oficyna Wydawnicza Polskiego Towarzystwa Zarządzania Produkcją, Zakopane.

Siegrist J. [1996], Adverse Health Effects of High-effort/Low-reward Conditions, „Journal of Occupational Health Psychology”, vol. 1, nr 1, https://doi.org/10.1037/10768998.1.1.27.

Sinclair R., Sears L., Zajack M., Probst T. [2010], A Multilevel Model of Economic Stress and Employee Well-Being [w:] Contemporary Occupational Health Psychology, eds J. Houdmont, S. Leka, R. Sinclair, Wiley-Blackwell, West Sussex.

Thompson S., Hopwood D. [2017], Workplace Safety: No Better Time than Now, http:// www.aspenrmg.com/Articles/workplace_safety_no_better_time_than_now.htm (data dostępu: 14.01.2017).

Weinstein M.B. [1997], Total Quality Safety Management and Auditing, CRS Press, Boca Raton, Florida.

\section{A Comprehensive Approach to Safety and Health Management in a Company - a Case Study}

(Abstract)

Nowadays, more and more organizations are using a system-based, proactive approach to the management of occupational safety and health (OSH). This requires that treatment of worker health and safety now be more complex and comprehensive than it has been. The aim of this paper is to present the diversity of OSH dimensions within the framework of the contemporary approach to OSH management.

The paper looks particularly at issues of organizational health and interventions addressing work-related stress. The second part of the article describes a case study of the implementation of a system-based OSH programme in one company, which undertook numerous technical, systemic and behavioral activities requiring the cooperation of many departments and individuals: OSH, HR, quality management and occupational medicine and Occupational Health Psychologists.

Keywords: health and safety management, OSH, organisational health, interventions, work-related stress. 